\title{
The relationship between phonotactic awareness and pronunciation in adult second language learners ${ }^{1}$
}

\section{A relação entre consciência fonotática e pronúncia em aprendizes adultos de língua estrangeira}

Hanna Kivistö-de Souza*

Universidade Federal de Santa Catarina

Florianópolis, Santa Catarina / Brasil

\begin{abstract}
This study examined to what extent L1 Brazilian Portuguese (BP) EFL learners are aware of L2 phonotactics and whether there would be a relationship between L2 phonotactic awareness and L2 pronunciation accuracy. The language learners were tested regarding their awareness of L2 onset consonant clusters with a lexical decision task presenting nonword stimuli with legal and illegal onset clusters. L2 pronunciation was measured with a Foreign Accent Rating Task. The results showed that L1 BP participants showed a high awareness concerning L2 phonotactics, not differing from L1 English speakers, $t(86)=.20, p=.83$. Furthermore, high phonotactic awareness was found to be related to higher accuracy in L2 pronunciation $(r=-.46, p<.001)$. The results suggest that phonotactics should be taught in foreign language classrooms since increasing learners' awareness might be beneficial for the accuracy of their L2 pronunciation.
\end{abstract}

KEYWORDS: phonological awareness; phonotactic awareness; L2 pronunciation; consonant clusters.

RESUMO: Este artigo examinou o grau de consciência fonotática em LE de aprendizes brasileiros de inglês e se a consciência fonotática em LE estaria positivamente relacionada à pronúncia em LE. Para medir a consciência sobre os clusters inicias da LE, os participantes completaram uma tarefa de decisão lexical que apresentava pseudopalavras com clusters possíveis e impossíveis. A

\footnotetext{
* hanna.kivistodesouza@gmail.com

${ }^{1}$ This manuscript forms part of the author's doctoral research conducted under the advisory guidance of Dr. Joan Carles Mora at the University of Barcelona (KIVISTÖ-DE SOUZA, 2015) and an earlier version of it was presented at the $8^{\text {th }}$ International Conference on Second Language Speech, New Sounds, in Aarhus, Denmark (June, 2016).
} 
pronúncia em LE foi medida através de um Teste de Julgamento de Nível de Sotaque Estrangeiro. Os resultados mostraram que os aprendizes apresentaram uma sensibilidade alta à fonotática da LE, não diferindo significativamente dos falantes nativos de inglês, $t(86)=.20, p=.83$. Além do mais, níveis mais altos de consciência fonotática surgiram relacionados a uma maior acuidade de pronúncia $(r=-.46, p<.001)$. Os resultados revelam a importância do ensino de fonotática na sala de aula estrangeira, uma vez que o aumento dessa consciência nos alunos poderia vir a ser benéfico para a pronúncia em LE.

PALAVRAS-CHAVE: consciência fonológica; consciência fonotática; pronúncia em LE; consoantes.

\section{Introduction}

Sensitivity to first language (L1) phonotactics is developed at an early age. Contrary to explicit awareness about phonology, implicit phonological awareness does not require instruction and develops naturally through language contact. Already at nine months, infants are sensitive to phonotactic violations in their L1 (JUSCZYK et al., 1993; MATTYS; JUSCZYK, 2001). The implicit learning mechanisms present in L1 phonotactic acquisition are no longer available in adult second language (L2) learning. Adult L2 learners' brains have already been committed to the neural and sensorimotor configurations of the L1 in such a way that an accurate perception and production of the L2 requires the overriding of pre-existing L1 neural connections (ELLIS, 2002), as well as the reconfiguration of the articulatory movements, which, since early infancy, have been wired for the pronunciation of L1 (HONIKMAN, 1964). As a consequence, adult L2 learners frequently perceive and produce L2 speech differently than native speakers.

In relation to L1 Brazilian Portuguese EFL learners' phonotactic acquisition, the production (CARDOSO; LIAKIN, 2009; CORNELIAN JÚNIOR, 2003; RAUBER, 2006) and perception (CARDOSO, JOHN; FRENCH, 2009; SILVEIRA, 2002) of L2 consonant clusters that do not exist in L1 has proven to be challenging for L1 Brazilian Portuguese learners of English. Non-target-like perception and production of L2 consonant clusters is likely to lead to communication breakdowns, which is why more attention should be paid to their acquisition in the foreign language classroom. However, only a few studies have focused on the acquisition of English phonotactics by L1 Brazilian Portuguese EFL learners, most studies having centered on investigating the acquisition of English segments (e.g., ALVES; ZIMMER, 2015; CRISTÓFARO SILVA; CAMARGOS, 2016; KLUGE, 2012). 
Phonotactic awareness refers to the language users' knowledge, in its majority non-verbalizable, about the target language phonological system in the phonotactic domain (KIVISTÖ-DE SOUZA, 2015). Whereas only a handful of studies exist concerning language learners' awareness of L2 phonotactics (ALTENBERG, 2005; MIKHAYLOVA, 2009; TRAPMAN; KAGER, 2009; WEBER; CUTLER, 2006), research in the area is in its infancy, and to the best of my knowledge, no prior study has investigated L1 Brazilian Portuguese learners of English. Moreover, previous research has centered on describing the quality and quantity of L2 learners' phonotactic awareness without relating it to participants' L2 pronunciation.

Therefore, the present study aimed to remedy these gaps by investigating the degree of phonotactic awareness, more specifically, awareness about L2 onset consonant clusters, in L1 Brazilian Portuguese learners of English. The study also sought to examine the relationship between L 2 phonotactic awareness and L2 pronunciation accuracy in order to determine whether the two would be positively related, a finding which would raise interesting pedagogical implications. This paper begins with a review of previous research on L2 phonotactic awareness and presents the onset consonant cluster inventories of the languages in question (American English and Brazilian Portuguese). Next, the study's methodology and results are explained. Finally, the results are examined in the light of previous research, and the pedagogical implications of the findings are discussed.

\section{Literature review}

\subsection{Phonotactic awareness}

Numerous studies exist regarding children's L1 phonological awareness in the process of literacy acquisition. However, awareness about the phonotactic domain in specific has been rarely examined either in the L1 or in the L2. Phonotactic awareness in the L2 can be defined as L2 phonological knowledge at the phonotactic domain, including knowledge about the L2 syllable structure, the permissible and impermissible sound combinations, as well as knowledge about their distribution (KIVISTÖ-DE SOUZA, 2015, p. 104).

Phonotactics are learned through initial conscious noticing from the frequency distributions present in the input the language learners are 
exposed to. Phonotactic learning is thus usage-based (ELLIS, 2002; 2005). To acquire a given phonotactic feature, the learner has to consciously notice it (SCHMIDT, 1995). Following the instance-based approach (e.g., ELLIS, 2002; 2005), learning is exemplar based and begins with the recognition of a prototypical exemplar with high functionality. We propose, following the weak interface position between explicit and implicit knowledge, that once the initial recognition has taken place, the explicitly noticed phonotactic feature will go through unconscious cognitive processing, and through priming and gradual strengthening it will become automatized so that it can be applied quickly and effortlessly in speech. In other words, it has become proceduralized knowledge; thus, it can be no longer be verbalized or accessed consciously.

Since phonotactic awareness is mostly based on proceduralized knowledge, accessing it through explicit tasks, such as verbalization of phonotactic rules or the manipulation of phonotactic segments, does not provide a comprehensive picture of an individual's phonotactic awareness. This is because most of the language users have not undergone phonetic training, neither in their L1 nor in their L2, and have not developed declarative representations of the underlying phonotactic knowledge. By contrast, all language users possess varying degrees of non-verbalizable, proceduralized phonotactic knowledge, as evidenced by the accurate perception and production of the target language syllabic structures and the sensitivity to phonotactic violations.

From the aforementioned reasons, most of the studies examining L1 and L2 users' phonotactic awareness have employed implicit testing methods. Native speakers have proven to be sensitive to phonotactic violations involving impossible onset consonant clusters (PRAAMSTRA; MEYER; LEVEL, 1994; TRAPMAN; KAGER, 2009). Native speakers are aware of phonotactic constraints at syllable boundaries and they are able to employ this knowledge in the segmentation of continuous speech (MCQUEEN, 1998; WEBER; CUTLER, 2006). Language users are also sensitive to the frequency distributions of lexical stress assignment in their L1 (VITEVITCH; LUCE; CHARLES-LUCE; KEMMERER, 1997), as well as to the phonotactic probabilities and frequencies in the L1 input (KÓVACS; RACSMÁNY, 2008; LUCE; PISONI, 1998; VITEVITCH; LUCE, 1998). It also appears that phonotactic awareness is gradient rather than categorical in native speakers (TRAPMAN; KAGER, 2009). 
Whereas L1 speakers often possess a rather solid awareness of their native phonotactics, less is known about language users' awareness of L2 phonotactics. Some studies suggest that non-native speakers possess phonotactic knowledge that is similar to L1 speakers and are able to apply it in a near-native-like manner (ALTENBERG, 2005; MIKHAYLOVA, 2009; TRAPMAN; KAGER, 2009). However, other studies suggest that L2 phonotactic awareness is affected by the transfer of L1 phonotactics and that L2 learners possess smaller amounts of phonotactic awareness than do native speakers (WEBER; CUTLER, 2006). Moreover, phonotactic awareness appears to be affected by language experience and use so that advanced language users perform in a more target-like manner than beginners (TRAPMAN; KAGER, 2009).

Overall, the results from previous studies suggest that although the L2 users might appear to possess phonotactic awareness that is similar to L1 speakers, this awareness is not applied as fast and as accurately in real-time tasks (HOLMES, 1996; MIKHAYLOVA, 2009; TRAPMAN; KAGER, 2009). Moreover, awareness about L2 phonotactics often fails to be successfully transformed into an accurate perception (ALTENBERG, 2005; DUPOUX et al., 2011; KABAK; IDSARDI, 2007) and production (ABRAHAMSSON, 2003; BOUDAOUD; CARDOSO, 2009; HANSEN, 2001; RAUBER, 2006) of L2 phonotactic features.

\subsection{Onset consonant clusters in General American English and Brazilian Portuguese}

Onset consonant clusters were chosen as the target structure to measure phonotactic awareness as the two languages in question differ greatly in terms of their consonant cluster inventories. In this section, the constraints posed by General American English and Brazilian Portuguese for consonant clusters in onset position are discussed. The section finishes with a revision of previous research on the acquisition of English consonant clusters by L1 Brazilian Portuguese EFL learners.

In General American English, up to three consonants (C) can occur in the syllable onset. In the case of a single consonant, any of the English consonants, except $/ \mathrm{y} /$, can occupy the syllable onset position. In the case of double clusters, two combinations are possible: either /s / + C, or obstruent + approximant. In the case of three-member clusters, the first consonant is obligatorily $/ \mathrm{s} /$, the second is a voiceless stop and the third is 
either a glide (/j, w/) or an approximant (/1, J/). General American English onset consonant clusters are seen in the following Table 1 :

\section{TABLE 1}

Onset consonant clusters of General American English

Adapted from Kivistö-de Souza (2015, p. 139) and summarized from

Cruttenden (2008, p. 254-259) and Yavaş (2011, p. 139-146)

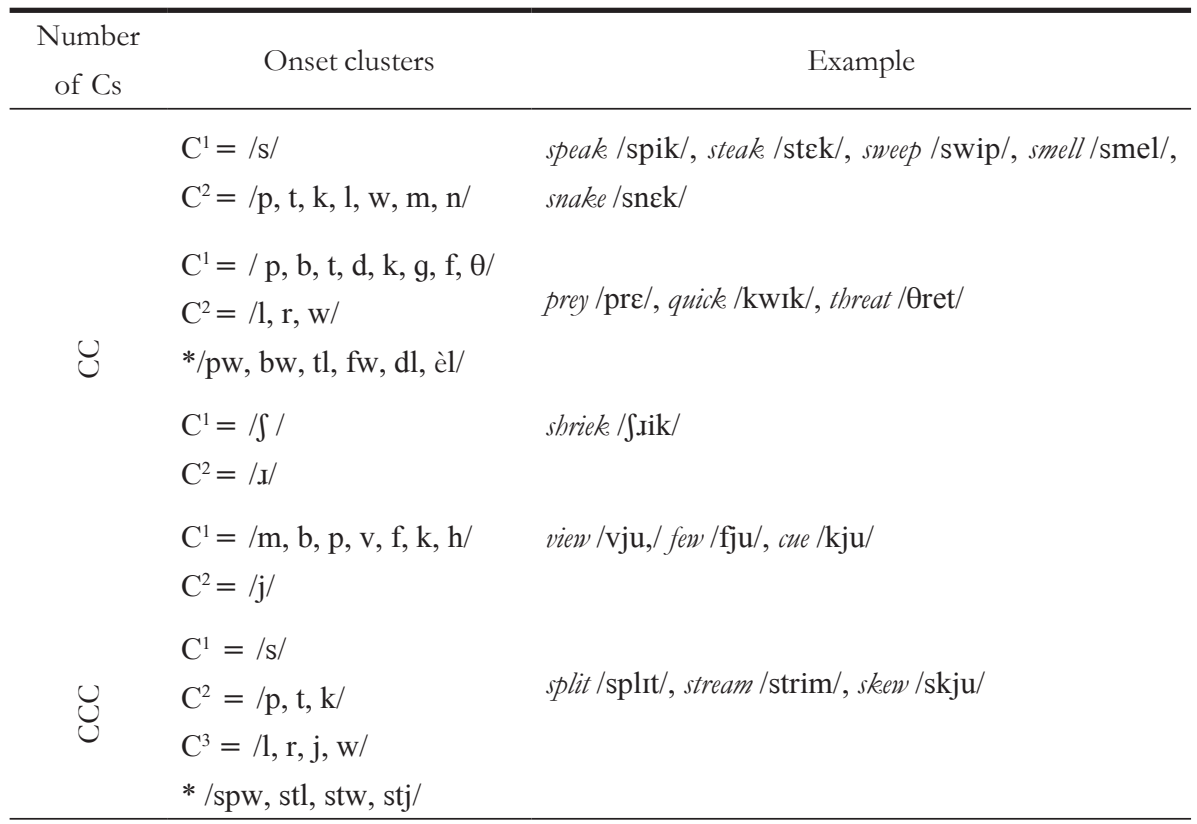

Brazilian Portuguese poses heavier restrictions on consonant clusters than General American English. In onset position, only one or two consonants are allowed. In the case of single consonant onset, any consonant, with the exception of $/ \mathrm{n} /, / K /$ which are limited to loanwords, and 'the weak r' can occur. In two-member clusters, the first member is a plosive or /f/, / v/ occurring only in loanwords. The second member of the cluster is obligatorily either / $1 /$ or the 'weak r'. Contrary to General American English, Brazilian Portuguese does not allow for three-member onset clusters and the restrictions posed on the two consonants that can form onset clusters are stricter in Brazilian Portuguese than in General American English as can be seen in the following Table 2: 
TABLE 2

Onset consonant clusters of Brazilian Portuguese

Adapted from Kivistö-de Souza (2015, p. 141) and summarized from Cristófaro Silva (2002, p. 156) and Azevedo (2004, p. 50)

\begin{tabular}{|c|c|c|}
\hline $\begin{array}{c}\text { Number } \\
\text { of CS }\end{array}$ & Onset Clusters & Example \\
\hline U & $\begin{array}{c}\mathrm{C}^{1}=/ \mathrm{p}, \mathrm{t}, \mathrm{k}, \mathrm{b} \\
\mathrm{d}, \mathrm{g}, \mathrm{f} /(/ \mathrm{v} /) \\
\mathrm{C}^{2}=/ \mathrm{l}, \mathrm{r} / \\
* / \mathrm{tl} /, / \mathrm{dl} /\end{array}$ & $\begin{array}{l}\text { pluma 'feather' /'plu.me/, prato 'plate' /'pra.tu/, } \\
\text { bloco 'block' /'blo.ku/, braço 'arm' /'bra.su/, } \\
\text { drama 'drama' /'dra.me/ }\end{array}$ \\
\hline
\end{tabular}

The acquisition of English onset consonant clusters by L1 Brazilian Portuguese speakers has shown that their perception and production is often challenging. Perception studies have indicated that L1 Brazilian Portuguese EFL learners frequently perceive an illusory prothetic vowel, [i], in English consonant clusters that are not allowed in the L1 (CARDOSO et al., 2009; SILVEIRA, 2002). The perception of illusory phones in sound combinations that would be illegal in the L1 has proven to be a frequently extended practice among language users in order to shape the input into the phonotactic patterns of L1 (e.g., DUPOUX et al., 1999; DUPOUX et al., 2011).

Production studies with L1 Brazilian Portuguese EFL learners suggest that, when faced with English consonant clusters that are impossible in L1, the preferred strategy is likewise the insertion of a prothetic vowel, [i]. This is done to break the cluster, so that the resulting sequence no longer violates L1 phonotactic constrains. For example, study would be pronounced as [is.tı.di] (CARDOSO; LIAKIN, 2009; CORNELIAN JÚNIOR, 2003; RAUBER, 2006; REBELLO; BAPTISTA, 2006).

The accurate perception and production of L2 onset clusters by L1 Brazilian Portuguese EFL learners thus requires that the L2 learners became aware of the differences between L1 and L2 phonotactic constraints, and more importantly, notice that the L2 allows for a larger number of onset clusters. Simply noticing the differences between L1 and L2 phonotactics is nevertheless not enough: the learner must also automatize the interlanguage phonotactic representations in order to be able to apply them in real-time speech perception and production (ELLIS, 2002). 


\section{Research questions}

The present study had two objectives. On the one hand, our aim was to investigate whether L1 Brazilian Portuguese learners of English are aware of the phonotactic constraints of L2, most specifically those involving onset consonant clusters. On the other hand, we sought to determine whether awareness about L 2 phonotactics is related to L2 pronunciation accuracy. The following research questions (RQs) and hypotheses (Hs) were formed:

RQ 1: Are L1 Brazilian Portuguese learners of English aware of English phonotactic constraints involving onset consonant clusters?

H1: It was hypothesized that advanced language learners would possess some degree of awareness about L2 phonotactics. Nevertheless, due to their developing L2 phonology, L1 Brazilian Portuguese EFL learners were expected to be less aware of English phonotactics than native English speakers.

RQ 2: To what extent is L2 phonotactic awareness related to L2 pronunciation accuracy?

H2: L2 phonotactic awareness and L2 pronunciation were expected to be somewhat related based on previous research in adjacent fields. Former studies indicate that language awareness and general language proficiency are positively related (BERGSLEITHNER; BORGES MOTA, 2013; CALDERÓN, 2013), as are verbalizable L2 phonological awareness and L2 pronunciation (KENNEDY; TROFIMOVICH, 2010). Furthermore, non-verbalizable L2 phonological awareness and the accurate production of target L2 segments has been found to correlate positively (MORA; ROCHDI; KIVISTÖDE SOUZA, 2014; BAKER; TROFIMOVICH, 2006). Finally, the employment of activities designed to raise awareness about L2 phonology has been found to be beneficial for the accuracy of L2 production (ALVES; MAGRO, 2011; COUPER, 2011; RAMÍREZ VERDUGO, 2006; SAITO, 2013; WREMBEL, 2005). Based on this body of research, we expected to find a positive relationship between L2 phonotactic awareness and L2 pronunciation. 


\section{Method}

Participants' awareness about L2 onset consonant clusters was tested with a lexical decision task, which presented possible and impossible English nonwords whose reaction times were recorded and taken as a measure of L2 phonotactic awareness. L2 pronunciation accuracy was measured with a Foreign Accent Rating task. The present section presents the participants of the study and the instruments employed.

\subsection{Participants}

The participants were 71 L1 Brazilian Portuguese learners of English (mean age $=26.01, S D=7.63)$ with upper-intermediate to advanced proficiency level of English as testified by their L2 vocabulary size ( $M$ $=4150.00, S D=571.83, \max =5,000-$ CEFR level C1: MILTON, 2010), measured with X_lex vocabulary size test (MEARA, 2005). The EFL learners were studying at the Federal University of Santa Catarina (UFSC) during the time of the data collection and mostly came from the South of Brazil (80\%), followed by the Southeast (15\%). All the participants had grown up in monolingual Brazilian Portuguese households and had begun studying English for the first time at school (AOL $M=9.28, S D=2.78$ ).

Altogether, the L1 Brazilian Portuguese participants had a limited exposure to English outside the university context. On average, they had been employing English $21.73 \%$ of the time $(S D=14.49)$ in the five years prior to data collection. Furthermore, only 13 percent of them were in constant contact with native English speakers. Their mean length of stay in English-speaking countries was 4.33 months $(S D=11.42)$ and 88 percent of them had never attended a course in English phonetics and phonology.

A group of native American English speakers $(n=19)$ was recruited among the exchange students attending university-level classes in Florianópolis with two objectives. First, they provided baseline data for native performance in a lexical decision task involving consonant clusters, and second, they judged the L1 Brazilian Portuguese participants' degree of foreign accent in the Foreign Accent Rating task. Their mean age was 23.83 years $(S D=6.76)$, and they all had been exposed to Brazilian Portuguese as adults for the first time (AOL $M=22.88, S D=5.67$ ). Their experience with Brazilian Portuguese was limited: 89 percent of them had stayed in Brazil for less than six months, and on average they had studied Portuguese for 
1.16 years $(S D=2.38)$. Moreover, only $11 \%$ of the native English speakers considered themselves fluent in Portuguese.

\subsection{Materials and procedure}

\subsubsection{Lexical decision task}

Participants' awareness about the phonotactic constraints involving L2 onset consonant clusters was tested in a lexical decision task. The task presented English words and nonwords, half of which conformed to English phonotactics (legal nonwords) and half of which did not (illegal nonwords). Participants' reaction time to the stimuli was recorded and taken as a measure for their phonotactic awareness. Previous research indicates responses to word stimuli being the fastest, followed by the responses to illegal nonword stimuli, whereas the reaction times to legal nonword stimuli have proven to be the slowest (MIKHAYLOVA, 2009; TRAPMAN; KAGER, 2009; STONE; VAN ORDEN, 1993). This is because lexical search for existing words ends quickly when the target is retrieved from the lexicon, whereas for legal nonwords, which conform to the phonotactic patterns of the target language, the lexical search goes on longer and finishes only when no target has been found. Lexical search for illegal nonwords finishes abruptly, because a language user with awareness of the target language phonotactics is able to immediately reject the target as an impossible lexical entry due to the violations of the phonotactic constraints (TRAPMAN; KAGER, 2009). Consequently, if the participants of the study were aware of the English phonotactic constraints involving onset consonant clusters, we were expecting to see the following response time (RT) effect: RT legal nonwords $>$ RT illegal nonwords $>$ RT words.

\subsubsection{Stimuli}

Three types of trials were created for the lexical decision task: legal nonwords, illegal nonwords and words. Additionally, distractor items (words and nonwords) without consonant clusters were created in order to disguise the real purpose of the task from the participants. It should be noted that the participants thought they were performing a simple lexical decision task, classifying stimuli into words and nonwords, being unaware that the purpose of the task was to examine their response latencies to the two types of nonwords. 
The legal nonwords were created by first contrasting the L1 and L2 onset consonant clusters. The clusters forming the onsets of the legal nonwords were selected among those which are permissible in General American English but impermissible in Brazilian Portuguese. Additional delimitation was made based on phonotactic probability measures so that the most frequently occurring two- and three-member onset clusters were chosen. Consequently, the following clusters were selected: /st, sp, sk, sl, $\theta_{\mathrm{I}}, \mathrm{sm}, \int \mathrm{I}, \mathrm{st} \mathrm{I}, \mathrm{sp} . \mathrm{I}, \mathrm{spl}$, sk. I/.

Once the legal nonword clusters were chosen, the phonotactic rules of General American English were purposely violated in order to create the illegal onset clusters. The non-occurrence of the illegal clusters was confirmed by entering them into the Phonotactic Probability Calculator (VITEVITCH; LUCE, 2004) and computing their phonotactic probabilities. As expected, their phonotactic probability was zero, confirming that they do not occur in General American English. The illegal clusters were: */sb, sd, sg, dl, tl, bz, s., zbl, zb., zgı, stl/.

After selecting the target clusters, the syllable rimes were created to form the legal and illegal nonwords. All the stimuli were monosyllabic and the syllable rimes always consisted of a high frequency vowel and a consonant so as to maintain the non-target part of the nonword as neutral as possible. With this aim, the Phonotactic Probability Calculator was used to compute phoneme positional probabilities for English vowels and consonants in rime position. The most frequent vowels were / $\mathrm{I}, æ, \varepsilon, \mathrm{a}, \mathrm{i} /$, and these were the vowels selected to occupy the nucleus of the nonwords. The most frequent consonants in coda position were / t, s, n, k, d, p, l/, and these were combined together with the vowels to form the rimes.

The word stimuli was created to resemble the legal nonwords as closely as possible so that lexical decision would be based on lexicality and not on phonetic properties. The onset consonant clusters for the word stimuli were the same as for the legal nonwords, namely, /sp, st, sk, sm, Sı, spl, spı, stı, skı/. A preliminary lexical analysis suggested that these clusters would not yield enough word items, which is why additional high frequency English clusters were selected: /t. , b., fl, pl, f. I/. These clusters are permissible in Brazilian Portuguese, contrary to the other clusters used in the stimuli. Nevertheless, this was not deemed a problem since the phonotactic permissibility of the word items was not the focus of the study. Additionally, it was intended that the word stimuli would be known to upper-intermediate 
EFL learners and that the word stimuli would not differ from the legal nonwords in terms of phonological neighborhood density and phonotactic probability values. Previous piloting of the task confirmed that intermediate L1 Brazilian Portuguese EFL learners were familiar with all the word items included in the data collection instrument.

Finally, a set of distractor nonwords and words was included in the stimuli in order to improve the reliability of the task. The distractor items did not have consonant clusters and were comparable in their phonological neighborhood density and phonotactic probability values to the legal nonwords and words. The nonword distractors were created by the researcher, while the word distractors were selected among the word stimuli used in the study conducted by Vitevitch and Luce (1999).

A female native speaker of American English recorded the stimuli in a soundproof booth at UFSC. The informant produced each nonword and word several times in randomized order. The most accurate repetition of the target items with the best auditory quality and clearest pronunciation were selected. The selected stimuli were auditorily and visually inspected in Praat (BOERSMA; WEENIK, 2013) for their correctness. More specifically, the pronunciation of each vowel, coda consonant, and. most importantly, onset consonant clusters was scrutinized and confirmed to correspond to their accurate realization. The final set of stimuli was preprocessed for presentation by normalizing it to the same peak level and removing any lowfrequency noise that might have been present in the recordings. The stimuli of the lexical decision task can be seen in Table 3 below. 
TABLE 3

Lexical decision trials

Test trials $(N=\mathbf{2 3 5})$

Nonword $(n=120)$

Word $(n=115)$

\begin{tabular}{|c|c|c|c|c|c|c|c|c|c|c|c|c|c|c|}
\hline \multicolumn{4}{|c|}{ Legal $(n=50)$} & \multicolumn{4}{|c|}{ Illegal $(n=50)$} & \multirow{2}{*}{\multicolumn{2}{|c|}{$\begin{array}{c}\text { Distractor } \\
\quad(n=20)\end{array}$}} & \multicolumn{3}{|c|}{ Word $(n=75)$} & \multirow{2}{*}{\multicolumn{2}{|c|}{$\begin{array}{c}\text { Distractor } \\
\quad(n=40)\end{array}$}} \\
\hline \multicolumn{2}{|c|}{$\mathrm{CC}$} & \multicolumn{2}{|c|}{$\mathrm{CCC}$} & \multicolumn{2}{|c|}{$\mathrm{CC}$} & \multicolumn{2}{|c|}{$\mathrm{CCC}$} & & & \multicolumn{2}{|c|}{ CC } & \multirow{2}{*}{ CCC } & & \\
\hline spaap & spap & splan & splæn & sbaap & sbap & zblan & zblæn & boit & boit & brag & score & & back & knife \\
\hline spak & spæk & spleet & split & sbak & sbæk & zbleet & zblit & chum & t fum & brain & spit & scream & bag & leg \\
\hline spas & spæs & splik & splik & sbas & sbæs & zblik & zblik & foom & fum & brave & skill & screen & boat & light \\
\hline spid & spid & splis & splis & sbid & sbid & zblis & zblis & gaud & gaud & bread & skin & scrub & book & long \\
\hline stap & stæp & sprad & sp.æd & sdap & sdæp & zbrad & zb.æd & geed & dzid & break & skip & split & cake & mouth \\
\hline steet & stit & spreen & sp.in & sdeet & sdit & zbreen & zb.in & ger & $\mathrm{g}^{\mathrm{c}}$ & breathe & small & sprain & case & night \\
\hline stel & stel & spret & sp.et & sdel & sdel & zbret & zb.set & gung & $\mathrm{g} \wedge \mathrm{y}$ & brick & smell & spread & cat & page \\
\hline stin & stın & spril & sp.ıl & sdin & $\operatorname{sdin}$ & zbril & zb.IIl & haif & haif & bride & smile & spring & coat & path \\
\hline stip & stip & straak & st.ıak & sdip & sdip & stlaak & stlak & looch & lut $\int$ & brief & smoke & straight & come & pick \\
\hline smaap & smap & strak & stıæk & sgaap & sgap & stlak & stlæk & naup & naup & bright & smooth & strain & date & ran \\
\hline smin & smin & strat & st.ıæt & sgal & sgæl & stlat & stlæt & ner & $n 3^{\circ}$ & bring & space & strap & dead & red \\
\hline smeek & smik & stred & stıed & sgeek & sgik & stled & stled & nug & nug & flag & spare & stream & dog & road \\
\hline smeet & smit & strid & st.ıId & sgeet & sgit & stlid & stlid & saip & saip & flake & speak & street & down & size \\
\hline smil & smil & skraap & sk.Iap & sgil & sgil & zgraap & zgıap & teing & tey & flame & speed & stress & fan & suit \\
\hline shran & f.æn & skrak & sk.ıæk & sran & S.Iæn & zgrak & zg.æk & teis & tes & flat & spell & strong & feed & sun \\
\hline shrees & S.is & skral & sk.ıæl & srees & s.is & zgral & zgıæl & teng & tey & flight & spill & & hair & time \\
\hline shreet & S.it & skrees & sk.is & sreet & S.it & zgrees & zg.is & thep & $\theta \varepsilon p$ & float & spoil & & head & walk \\
\hline shrik & S.IIk & skrid & sk.ıId & srik & S.IIk & zgrid & zg.ıId & vek & vek & floor & stage & & & wall \\
\hline skas & skæs & & & dlas & dlæs & & & weim & wem & frame & stain & & & wash \\
\hline skeek & skik & & & dleek & dlik & & & zaat & zat & freeze & stair & & house & wife \\
\hline skes & skes & & & dles & dles & & & & & fresh & state & & & \\
\hline sket & sket & & & dlet & dlet & & & & & frog & steak & & & \\
\hline skis & skis & & & dlis & dlis & & & & & place & steam & & & \\
\hline thrap & $\theta æ p$ & & & bzap & bzæp & & & & & plan & step & & & \\
\hline threek & O.lik & & & bzeek & bzik & & & & & plane & still & & & \\
\hline threk & $\theta_{\text {IIk }}$ & & & bzek & bzek & & & & & plate & trade & & & \\
\hline thren & $\theta$.Ien & & & bzen & bzen & & & & & plot & treat & & & \\
\hline thris & $\theta_{\text {.IIS }}$ & & & bzis & bzIs & & & & & plug & trick & & & \\
\hline slad & slæd & & & tlad & tlæd & & & & & scar & trim & & & \\
\hline slas & slæs & & & tlas & tlæs & & & & & school & truth & & & \\
\hline slen & slen & & & tlen & tlen & & & & & & & & & \\
\hline sles & sles & & & tles & tles & & & & & & & & & \\
\hline
\end{tabular}




\subsubsection{Task structure}

A lexical decision task was chosen to measure participants' awareness about L2 phonotactics due to its ability to capture listeners' instinctive phonotactic knowledge through reaction time measurements in real time, before any re-mapping procedures due to L1 phonotactic expectations would have time to emerge. Additionally, a lexical decision task does not focus the listener's attention on phonotactics, but rather on lexicality, and does not require the participant to verbalize any distributional rules, meaning that non-verbalizable phonotactic awareness can be readily tested. As was seen earlier, the majority of phonotactic awareness is based on non-verbalizable knowledge, making the use of implicit testing methods a priority.

Lexical decision tasks have been widely employed in psycholinguistic research to measure, among other things, phonotactic frequency and phonological neighborhood effects (VITEVITCH; LUCE, 1998), orthographic effects (PEXMAN; LUPKER; JARED, 2001), phonological processing (PRAAMSTRA et al., 1994), semantic processing (HINO; LUPKER; PEXMAN, 2002), syntactic priming (WRIGHT; GARRETT, 1984), and bilingual lexical processing (PALLIER; COLOMÉ; SEBASTIÁNGALLÉS, 2001).

Previous research also indicates that lexical decision tasks can be successfully used to measure phonotactic awareness through reaction time measurements. Rejection of illegal nonwords has proven to be faster than that of legal nonwords, given that the lexical search for nonwords with an illegal onset is quickly blocked (MIKHAYLOVA, 2009; TRAPMAN; KAGER, 2009; STONE; VAN ORDEN, 1993). Previous studies have also determined that response latencies to words are faster than to legal nonwords, since the lexical search ends faster for words than for nonwords (FORSTER; CHAMBERS, 1973; VITEVITCH; LUCE, 1999). In other words, response latencies to legal and illegal nonwords can be employed to determine language users' awareness about phonotactics: should no awareness about the permissible and impermissible clusters exist, no differences would be observed in the reaction times between the two nonword types.

The lexical decision task employed in the present study was created and administered with DmDx software (FORSTER; FORSTER, 2012). It consisted of 235 test trials, preceded by six practice trials, which provided feedback on speed in order to encourage participants to respond as fast as 
they could. Stimuli was presented auditorily only, in a randomized order. Participants' task was to decide, by pressing the corresponding answer key, whether the heard item was an existing word in English or not. Participants were instructed to answer as fast and as accurately as possible. Since the 'no' responses (nonwords) were the target of the study, the key for 'no' responses was always located under the participants' dominant hand, which was ensured by having a left-handed and a right-handed version of the task.

The lexical decision task was carried out individually in a quiet room at UFSC with a laptop computer and headphones. The lexical decision task was the first of several phonological awareness tasks the participants performed during the data collection session. At the beginning of the data collection session, participants signed a consent form and filled out a language background questionnaire.

The data from the lexical decision task came in the form of response times and response accuracy. The manuscript reports only on the response time data, as this is the primary data to measure phonotactic awareness. For the reaction time analyses, only the items with correct answers were included in the analyses, following that set forth in previous research (FORSTER; CHAMBERS, 1973; VITEVITCH; LUCE, 1998). To obtain more precise response latency measures, corrected reaction times were employed in the analyses. Corrected reaction times were calculated by subtracting the stimulus duration from the total reaction time (LUCE; PISONI, 1998; TRAPMAN; KAGER, 2009). Mean response times for each participant in each of the three conditions (word, legal nonword, illegal nonword) were computed.

Additionally, to obtain a single score representing participants' phonotactic awareness and to enable comparisons to L2 pronunciation, a Phonotactic Awareness Score was computed by employing the following formula: 1-(RT illegal/RT legal)*100. The resulting number represents the difference in percentage between the reaction time of the illegal nonwords and the legal nonwords. We hypothesized that the larger the difference, the more accurately the participant would distinguish between the illegal and legal nonwords. In other words, the larger the distance, the more awareness the participant shows of the English onset consonant clusters. If the distance in the reaction times would be negative or very small, the participant would not be discerning between the legal and illegal nonwords, and would thus not show phonotactic awareness of English consonant clusters. 


\subsubsection{Foreign accent rating task}

The accuracy of L2 pronunciation was evaluated with a Foreign Accent Rating task, which has been widely employed in L2 speech research (e.g., BONGAERTS; VAN SUMMEREN; PLANKEN; SCHILS, 1997; FLEGE, 1988; FLEGE; FLETCHER, 1992; FLEGE et al., 2006; MACKAY et al., 2006; MAGEN, 1998; PISKE; MACKAY; FLEGE, 2001). Foreign accent rating tasks present $\mathrm{L} 2$ users' speech samples to a panel of native or non-native judges who rate them for their degree of foreign accent. Subjective judgments of language users obtained in this way are highly uniform, and language users, to a large extent, tend to agree when judging L2 speech (FLEGE; FLETCHER, 1992; PISKE et al., 2001; SCHMID; HOPP, 2014).

The L1 Brazilian Portuguese participants' L2 speech samples were elicited through a delayed sentence repetition paradigm (e.g., FLEGE; MUNRO; MACKAY, 1995; FLEGE et al., 2006; MACKAY; FLEGE; IMAI, 2006; PISKE et al., 2001; TROFIMOVICH; BAKER, 2006). A delayed sentence repetition paradigm eliminates the effects of reading proficiency and orthography, which are present in reading aloud tasks, while providing highly controlled and usually fluent speech samples. In a delayed sentence repetition task, the informant is presented with words or sentences spoken by a native speaker of the target language and is asked to repeat the targets after a pause or a distractor item ('delayed repetition'). With this aim, the targets are embedded into mini-dialogs, such as a question-answer, so that direct imitation of the native speaker model is impossible, as the target is followed by a distractor sentence (FLEGE et al., 1995).

Two target sentences were elicited through a delayed sentence repetition task in the present study. The sentences were designed so that they would present familiar vocabulary and a wide variety of L2 phones in order to obtain representative pronunciation samples for each foreign language learner. Additionally, both sentences were designed to include likely segmental, phonotactic, and prosodic problem areas for L2 speakers, such as difficult consonants and vowels, consonant clusters, unstressed function words, and nuclear stress assignment. The two target sentences were: 'Strong Steve killed a huge snake' and 'Their new job taught them many things'.

The delayed sentence repetition task was performed in the beginning of the data collection session. The L1 Brazilian Portuguese participants listened to question-answer dialogs in which the answer corresponded to the 
target sentence they were asked to repeat, and the question corresponded to the distractor. The model answers were read by a female native speaker of American English. Participants sat in front of a Shure SM58 unidirectional microphone and a Sony PCM-M10 recorder with sampling frequency set to $44100 \mathrm{~Hz} / 16-b i t$ and listened to the mini-dialogs from headphones. The participants did not see the orthographic representation of the sentences at any point. The structure of each mini-dialog was the following: first participants heard a question, followed by a $100 \mathrm{~ms}$ pause, and then the answer. They then heard the question again, after which they had $500 \mathrm{~ms}$ to repeat the previously heard answer. If the participant made a mistake or was unable to repeat the answer, the dialog was played again.

The L1 Brazilian Portuguese participants' L2 productions were extracted from the delayed sentence repetition task and preprocessed for presentation. Low-frequency noise was eliminated and the sentences were normalized to the same peak level, after which the 142 sentences ( 2 sentences $x 71$ participants) were presented to the native English participants of the study who judged their pronunciation accuracy in a Foreign Accent Rating task.

The Foreign Accent Rating task was created and administered in Praat (BOERSMA; WEENIK, 2013). It consisted of three blocks: a practice block with eight repetitions of the sentence 'She started to work in the school canteen', as pronounced by eight randomly selected L1 Brazilian Portuguese learners; the Sentence 1 block; and the Sentence 2 block. The practice block was included in order to familiarize the raters with the range of foreign accents present in the task. In the actual test, all of the repetitions of the sentence, 'Strong Steve killed a huge snake', were presented first, followed by all the repetitions of the sentence, 'Their new job taught them many things'. The order of the blocks was fixed, whereas the order of the trials within the blocks was randomized. The task was self-paced and the L1 American English listeners were allowed to pause at any point. The judges listened to the sentences one by one and rated them on a nine-point Likert scale ( $1=$ no foreign accent, $9=$ a very heavy foreign accent). Instructions were given to use the whole scale when rating the speech samples. To increase task reliability, repetitions of the two sentences by five native English speakers were also included in the task. Consequently, the Foreign Accent Rating task consisted of eight practice trials and 152 test trials. 
The foreign accent judgment task was carried out individually in a quiet room at UFSC. The structure of each trial was the following. The target sentence was heard through the headphones, immediately after which the rater saw the orthographic representation of the sentence together with the rating scale. Responses were given by clicking the corresponding number on the scale. The listeners had the option to re-listen to each speech sample once if required.

Each L1 Brazilian Portuguese participant received a foreign accentedness rating from each of the 19 native English judges for the two test sentences. To create a Foreign Accent Score representative of each participant's L2 pronunciation accuracy, the judges' mean ratings of the two sentences were computed, preceded by the confirmation that the two test sentences shared a strong positive correlation $(r=.693, n=71, p<.001)$. Inter-rater reliability, as measured by Cronbach's Alpha, was .96.

\section{Results}

\subsection{Awareness of L2 phonotactics}

To determine whether the L1 Brazilian Portuguese EFL learners had developed an awareness of English phonotactic rules involving initial consonant clusters, reaction times between words, legal nonwords, and illegal nonwords were compared and contrasted to L1 American English participants' reaction times. It was expected that if the participants had developed an awareness of L2 phonotactics, they would show a clear response time effect by reacting the slowest to legal nonwords, then to illegal nonwords, and the fastest to words. Descriptive statistics can be seen in Table 4. 
TABLE 4

Mean reaction times (ms) to stimulus types

\begin{tabular}{lccccc}
\hline & \multicolumn{2}{c}{$\mathbf{L 1} \mathbf{B P}(\boldsymbol{n}=\mathbf{7 1})$} & & \multicolumn{2}{c}{$\mathbf{L 1} \mathbf{A m E}(\boldsymbol{n}=\mathbf{1 9})$} \\
\cline { 2 - 3 } \cline { 5 - 6 } Stimulus type & $\mathrm{M}$ & $\mathrm{SD}$ & & $\mathrm{M}$ & $\mathrm{SD}$ \\
Legal nonword & 731.06 & 180.94 & & 463.10 & 108.72 \\
Illegal nonword & 523.93 & 184.92 & & 354.83 & 137.50 \\
Word & 430.63 & 103.99 & & 334.28 & 87.97 \\
\hline
\end{tabular}

A mixed ANOVA was conducted with Stimulus Type (illegal nonword/ legal nonword/word) and L1 (BP/AmE) as independent variables, and Reaction Time as the dependent variable. The ANOVA showed a significant main effect from both the Stimulus Type and L1, as well as a Stimulus Type x L1 interaction. The interaction effect was due to the fact that, whereas for the L1 Brazilian Portuguese participants the reaction times to all three stimulus types differed significantly from each other, for the L1 American English participants, the reaction times between the illegal nonwords and words did not differ significantly $(p=.47)$. The main effect of $L 1$ was due to the fact that the L1 American English speakers responded significantly faster than did the L1 Brazilian Portuguese speakers in all stimulus categories. These results indicate that both participant groups showed a clear response time effect, revealing an awareness of English phonotactics (Figure 1).

FIGURE 1. Reaction time effect across stimulus types and L1 participants.

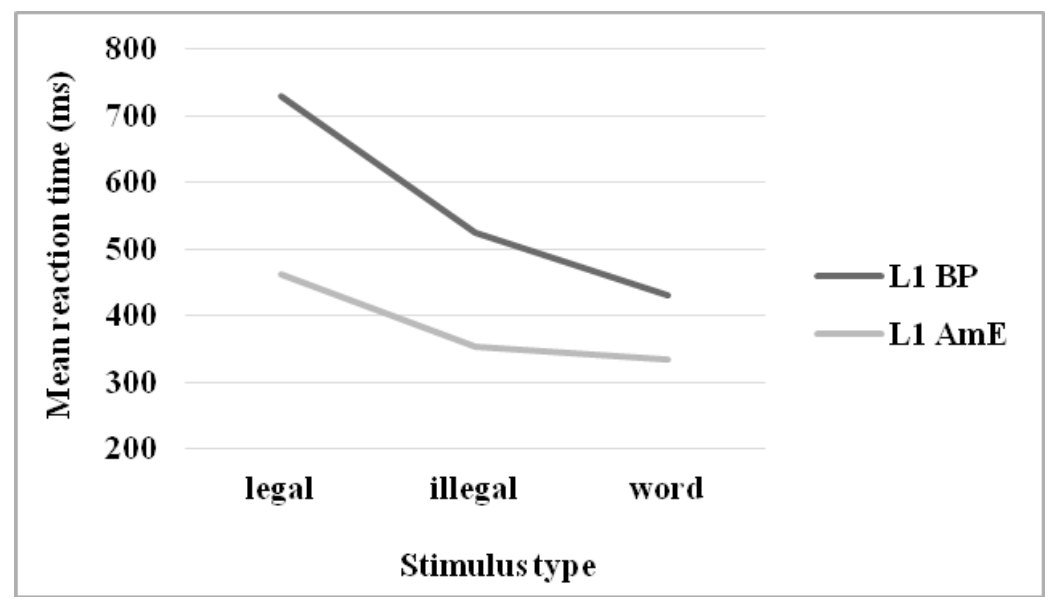


To further examine the differences between L1 Brazilian Portuguese EFL learners and native English participants, an independent samples t-test was conducted between the two L1 groups using the Phonotactic Awareness Score as the dependent measure. No significant differences were found between the L1 Brazilian Portuguese participants $(M=29.00, S D=14.11)$ and the L1 American English participants $(M=28.21, S D=13.32)$ in terms of their phonotactic awareness scores, $t(86)=.20, p=.83$.

Taken together, the results from the two analyses indicate that, though responding slower than native English speakers, L1 Brazilian Portuguese EFL learners presented a high awareness of English phonotactics. This was evident in their expected response time effect as well as in their phonotactic awareness score being comparable to the native English speakers.

\subsection{L2 phonotactic awareness and L2 pronunciation accuracy}

The second research question sought to determine whether L2 phonotactic awareness would be related to L2 pronunciation accuracy. The relation between L 2 phonotactic awareness, as measured by the Phonotactic Awareness Score, and L2 pronunciation, as measured by the Foreign Accent Score, can be seen in Figure 2.

FIGURE 2. Scatterplot of the relation between

L2 phonotactic awareness and L2 pronunciation accuracy.

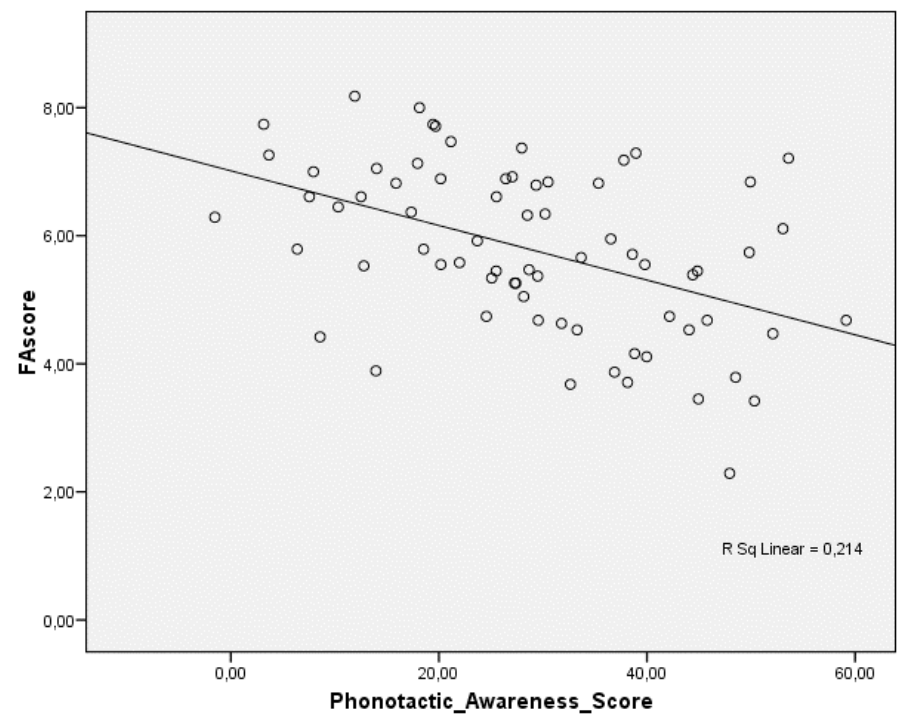


A Pearson product moment correlation revealed a medium-sized negative correlation between phonotactic awareness and L 2 pronunciation, indicating that high levels of phonotactic awareness were associated with low foreign accent ratings $(r=-.463, n=71, p<.001)$. In other words, participants with a higher degree of $\mathrm{L} 2$ phonotactic awareness also had high L2 pronunciation accuracy. The coefficient of determination indicated that the variables shared $23 \%$ of their variance.

The results to the second research question confirmed the hypothesis that L2 phonotactic awareness and L2 pronunciation would be positively related. Therefore, the results from the present research extend the positive relation previously observed for language awareness and language proficiency (CALDERÓN, 2013), verbalizable L2 phonological awareness and L2 pronunciation (KENNEDY; TROFIMOVICH, 2010) and nonverbalizable L2 phonological awareness and accurate production of target segments (MORA et al., 2014) to L2 phonotactic awareness and L2 pronunciation.

\section{Conclusion and discussion}

The present study examined L1 Brazilian Portuguese EFL learners' awareness about L2 phonotactic constraints involving onset consonant clusters and whether L2 phonotactic awareness would be related to the accuracy of L2 pronunciation. The results showed, on the one hand, that the language learners of the study possessed large amounts of non-verbalizable knowledge about the $\mathrm{L} 2$ phonotactics. On the other hand, it was discovered that language learners with high levels of phonotactic awareness also had higher L2 pronunciation accuracy than did participants who presented lower levels of L2 phonotactic awareness.

The results from the two analyses conducted to examine L1 Brazilian Portuguese EFL learners' awareness about English phonotactics suggest that upper-intermediate/advanced L1 Brazilian Portuguese EFL learners possess a fair amount of non-verbalizable knowledge about English phonotactics, not differing significantly from native English speakers. The only statistically significant difference observed between the two L1 groups concerned response speed: native English speakers reacted significantly faster than the L2 learners to all stimulus categories.

These results did not support the hypothesis we posited that language learners would show a lower degree of phonotactic awareness than native 
speakers due to their developing interlanguage phonology. However, the results obtained in the present study are not unheard of in previous research employing lexical decision tasks with non-native speakers. Trapman and Kager (2009) and Mikhaylova (2009) found that L2 speakers responded slower than L1 speakers, yet they possessed knowledge about the target language phonotactics that was similar to that of native speakers.

Nevertheless, we should not interpret these results as upperintermediate/advanced L1 Brazilian Portuguese learners of English having a native-like command of English phonotactics. This study only employed one task type (online lexical decision) and one target structure (onset consonant clusters). If one were to employ a more gradient task type, such as word-likeness judgments or gating tasks, the results might be different. It is also possible that becoming aware of the internal organization of the syllable, namely, which phones can and cannot appear together in the L2, is easier than learning the difference between L1 and L2 syllable structures (CCVC vs. CV.CVC such as school-'escola', for example).

The results from the present study should be instead interpreted as the learners having developed some awareness of L2 phonotactics but not having developed automatized interlanguage phonotactic representations of them. In other words, the learners had noticed the differences between L1 and L2 onset consonant clusters, which following Schmidt's Noticing Hypothesis (1995) is the first step in accurate language acquisition. However, the learners had not yet developed fully automatized interlanguage phonotactic representations. This is supported, on the one hand, by the results of the present study: the L1 Brazilian Portuguese EFL learners responded slower than the native speakers clearly revealing the smaller degree of automatization of the underlying representations. On the other hand, this interpretation is supported by previous research with L1 Brazilian Portuguese ELF learners indicating the frequent perception and production problems with English onset clusters (e.g., CARDOSO et al., 2009; CARDOSO; LIAKIN, 2009: RAUBER, 2006; REBELLO; BAPTISTA, 2006; SILVEIRA, 2002).

The second finding of the study is that L2 phonotactic awareness was positively related to L2 pronunciation accuracy in L1 Brazilian Portuguese learners of English. It should be noted that the causality of this relation cannot be established with the current data, although we have strong theoretically founded reasons to believe that either variation in L2 
phonotactic awareness leads to variation in L2 pronunciation (and not the other way around) or that the relationship between the two is reciprocal. The first scenario (phonotactic awareness $\rightarrow$ L2 pronunciation) is supported by the large body of language awareness research based on Schmidt's Noticing Hypothesis (1995) and on the notion that the accurate acquisition and production of a given linguistic feature requires it to have been consciously noticed. Likewise, the majority of L2 speech research follows the view that some, if not most, of the pronunciation mistakes have a perceptual origin as postulated by Flege (1995) and Best (1995).

However, the possibility that the relationship between L2 phonotactic awareness and L2 pronunciation is reciprocal (L2 phonotactic awareness $\leftarrow$ L2 pronunciation) is also possible. In this scenario, learners with higher L2 phonotactic awareness develop higher accuracy in L2 pronunciation, because the increased accuracy in pronunciation enables the relocation of attention to less salient features (VANPATTEN, 1996) and leads to more noticing of additional phonotactic aspects. Whatever the directionality of the relationship proves to be, the finding that the relationship between L2 phonotactic awareness and L2 pronunciation is positive brings interesting practical implications.

Although the participants in the present study showed a high awareness of English phonotactics, the results to the second research question suggest that teaching phonotactics is beneficial for L2 pronunciation. Despite the participants' seemingly high level of L2 phonotactic awareness, the phonotactic constraints of the native language are still likely operating in their L2 speech processing, thus resulting in a negative transfer (WEBER; CUTLER, 2006). Altenberg's (2005) participants (L1 Spanish learners of English) also presented a high degree of phonotactic awareness but were still unable to apply that information in real-time L2 perception and production. What this suggests is that even though language learners may show a high level of L2 phonotactic awareness, as was the case with the L1 Brazilian Portuguese participants in the present study, they would still benefit from practice in order to develop more automatized processing (ELLIS, 2002).

Practice is necessary for $\mathrm{L} 1$ articulatory movements to be reconfigured to the effortless production of L2 consonant clusters. Additionally, greater experience with listening to the target language should aid L2 users in taking advantage of the L2-specific phonotactic constraints (WEBER; CUTLER, 2006). In other words, greater experience gained by listening to an input with 
a high frequency of onset s-clusters, for example, might gradually lead to the language learner's acceptance of these sequences as natural in L2 without the need to resort to the insertion of epenthetic illusory vowels.

Whether regular L2 input is enough to make the phonotactic constraints of L2 perceivable to foreign language learners is a matter of future studies. What is clear from previous research is that the employment of activities used to raise L2 learners' awareness about the target language is beneficial in making aspects of L2 phonology more salient for language learners (ALVES; MAGRO, 2011; CEBRIAN; CARLET 2014; COUPER, 2011; RATO, 2013; SAITO; WU, 2014; WREMBEL, 2005). With lowerlevel learners, the employment of consciousness-raising activities, such as explicit teaching or the employment of enhanced input, might be especially beneficial given that beginners first need to develop their awareness of L2 phonotactics. With higher-level learners, once their awareness of L2 phonotactics has been developed, the employment of articulatory and perceptual training activities, for example, could be especially beneficial, as these would promote more automatized L2 speech processing and more fluent and accurate L2 output. Finally, future studies should compare the different methods (e.g., explicit teaching, theoretical lectures, pronunciation drills, laboratory training, etc.) to increase L2 phonotactic awareness in order to determine their effectiveness.

\section{References}

ABRAHAMSSON, N. Development and recoverability of L2 codas: A longitudinal study of Chinese-Swedish interphonology. Studies in Second Language Acquisition, Cambridge, v. 25, n. 3, p. 313-349, Sept. 2003.

ALTENBERG, E. The judgment, perception and production of consonant clusters in a second language. International Review of Applied Linguistics in Language Teaching, Berlin, v. 43, n. 1, p. 53-80, Jan. 2005.

ALVES, U. K.; MAGRO, V. Raising awareness of L2 phonology: Explicit instruction and the acquisition of aspirated /p/ by Brazilian Portuguese speakers. Letras de Hoje, Porto Alegre, v. 46, n. 3, p. 71-80, July 2011.

ALVES, U. K.; ZIMMER, M.C. Percepção e produção dos padrões de vot do inglês por aprendizes brasileiros: $\mathrm{O}$ papel de múltiplas pistas acústicas sob uma perspectiva dinâmica. Alfa, São Paulo, v. 59, n.1, p. 157-180, Jan. 2015.

AZEVEDO, M. Portuguese: A linguistic introduction. New York: Cambridge University Press. 2004. 
BAKER, W.; TROFIMOVICH, P. Perceptual paths to accurate production of L2 vowels: The role of individual differences. International review of Applied Linguistics in Language Teaching, Berlin, v. 44, n. 3, p. 231-250, Nov. 2006.

BERGSLEITHNER, J.; BORGES MOTA, M. Investigating relationships among noticing, working memory capacity, and accuracy in L2 oral performance. In: BERGSLEITHNER, J.; FROTA, S.; YOSHIOKA, J. (Org.). Noticing and second language acquisition: Studies in honor of Richard Schmidt. Honolulu: University of Hawai'i, National Foreign Language Resource Center, 2013. p. 151-168.

BEST, C. T. A direct realist perspective on cross-language speech perception. In: STRANGE, W. (Org.). Speech perception and linguistic experience: Issues in crosslanguage research. Timonium: York Press, 1995. p. 171-204.

BIALYSTOK, E. et al. Degree of foreign accent in English sentences produced by Korean children and adults. Journal of Phonetics, Amsterdam, v. 34, n.1, p.153-175, Jan. 2006.

BOERSMA, P.; WEENIK, D. Praat: doing phonetics by computer (Version 5.3.70). Computer software. 2013. Retrieved from: $<$ http://praat.org $>$. Accessed on: $10^{\text {th }}$ Oct. 2016..

BONGAERTS, T. et al. Age and ultimate attainment in the pronunciation of a foreign language. Studies in Second Language Acquisition, Cambridge, v. 19, n. 4, p. 447-465, Dec. 1997.

BOUDAOUD, M.; CARDOSO, W. The variable acquisition of /s/ + consonant onset clusters in Farsi-English interlanguage. In: BOWLES, M. et al. (Org.). Proceedings of the $10^{\text {th }}$ Generative Approaches to Second Language Acquisition Conference. Somerville: Cascadilla Proceedings Project, 2009. p. 86-104.

CALDERÓN, A. The effects of L2 learner proficiency on depth of processing, levels of awareness, and intake. In: BERGSLEITHNER, J.; FROTA, S.; YOSHIOKA, J. (Org.). Noticing and second language acquisition: studies in honor of Richard Schmidt. Honolulu: University of Hawai'i, National Foreign Language Resource Center, 2013. p. 103-122.

CARDOSO, W.; JOHN, P.; FRENCH, L. The variable perception of /s / + coronal onset clusters in Brazilian Portuguese English. In: WATKINS, M. A.; RAUBER, A.; BAPTISTA, B. O. (Org.). Recent research in second language phonetics/ phonology: Perception and production. Newcastle upon Tyne: Cambridge Scholars, 2009. p. 203-231.

CARDOSO, W.; LIAKIN, D. When input frequency patterns fail to drive learning: The acquisition of $\mathrm{s} C$ onset clusters. In: WATKINS, M. A.; RAUBER, A.; BAPTISTA, B. O. (Org.). Recent research in second language phonetics/ phonology: Perception and production. Newcastle upon Tyne: Cambridge Scholars, 2009. p. 174-202. 
CEBRIAN, J.; CARLET, A. Second language learners' identification of target language phonemes: A short-term phonetic training study. Canadian Modern Language Review, Toronto, v. 70, n. 4, p. 474-499, Nov. 2014.

CORNELIAN Jr., D. Brazilian learners' production of initial / s/ clusters: Phonological structure and environment. 2003. 150f. Thesis (Master's in English Language and Literature) - Federal University of Santa Catarina, Programa de Pós-Graduação em Inglês, Florianópolis, SC., 2003.

COUPER, G. What makes pronunciation teaching work? Testing for the effect of two variables: socially constructed metalanguage and critical listening. Language Awareness, London, v. 20, n.3, p. 159-182, Oct. 2011.

CRISTÓFARO SILVA, T. Fonética e fonologia do Português: Roteiro de estudos e guia de exercícios. 6. ed. São Paulo: Contexto, 2002.

CRISTÓFARO SILVA, T.; CAMARGOS, M.A. Conhecimento fonológico e apropriação de róticos em inglês L2 por falantes nativos de português brasileiro. Ilha do Desterro, Florianópolis, v. 69, n.1, p. 49-60, Jan. 2016.

CRUTTENDEN, A. Gimson's pronunciation of English. 7. ed. London: Hodder Education, 2008.

DUPOUX, E. et al. Epenthetic vowels in Japanese: a perceptual illusion? Journal of Experimental Psychology: Human Perception and Performance, Washington, v.25, n.6, p. 1568-1578, June 1999.

DUPOUX, E. et al. Where do illusory vowels come from? Journal of Memory and Language, Berlin, v. 64, n. 3, p. 199-210, Oct. 2011.

ELLIS, N. C. Reflections on frequency effects in language processing. Studies in Second Language Acquisition, Cambridge, v. 24, v. 2, p. 297-339, June 2002.

ELLIS, N. C. At the interface: Dynamic interactions of explicit and implicit language knowledge. Studies in Second Language Acquisition, Cambridge, v. 27, n. 2, p. 305-352, June 2005.

FLEGE, J. Factors affecting degree of perceived foreign accent in English sentences. The Journal of the Acoustical Society of America, New York, v. 84, n. 1, p. 70-79, July 1988.

FLEGE, J. Second language speech learning, theory, findings and problems. In: STRANGE, W. (Org.). Speech perception and linguistic experience: Issues in crosslanguage research. Timonium: York Press, 1995. p. 233-277.

FLEGE, J.; FLETCHER, K. Talker and listener effects on degree of perceived foreign accent. The Journal of the Acoustical Society of America, New York, v. 91, n. 1, p. 370-389, July 1992. 
FLEGE, J. et al. Degree of foreign accent in English sentences produced by Korean children and adults. Journal of Phonetics, Amsterdam, v. 34, n.1, p.153-175, Jan. 2006 FLEGE, J.; MUNRO, M.; MACKAY, I. R. A. Factors affecting strength of perceived foreign accent in a second language. The Journal of the Acoustical Society of America, New York, v. 97, n. 5, p. 3125-3134, May 1995.

FORSTER, K. I.; FORSTER, J. C. DMDX (Version 4.0.6.0). Computer software. 2012. Retrieved from: < http://www.u.arizona.edu/ jforster/dmdx.htm>. Accessed on: Oct. $10^{\text {th }} 2016$.

FORSTER, K.; CHAMBERS, S. Lexical access and naming time. Journal of verbal learning and verbal behavior, Berlin, v. 12, n. 6, p. 627-635, Dec. 1973.

HANSEN, J. Linguistic constraints on the acquisition of English syllable codas by native speakers of Mandarin Chinese. Applied Linguistics, Oxford, v. 22, n. 3 , p. 338-365, Sept. 2001.

HINO, Y.; LUPKER, S.; PEXMAN, P. Ambiguity and synonymy effects in lexical decision, naming and semantic categorization tasks: Interactions between orthography, phonology and semantics. Journal of Experimental Psychology: Learning, Memory and Cognition, Washington, v. 28, n. 4, p. 686-713, May 2002.

HOLMES, F. Cross-language interference in lexical decision. Speech, Hearing and Language, Washington, v. 9, n.1 p. 57-71, January, 1996. Retrieved from: $<$ http://www.phon.ucl.ac.uk/home/shl9/contents.htm>. Accessed on: Oct.10 ${ }^{\text {th }}$ 2016.

HONIKMAN, B. Articulatory settings. In: ABERCROMBIE, D. et al. (Org.). In Honour of Daniel Jones. London: Longman, 1964. p. 73-84.

JUSCZYK, P. et al. Infants' sensitivity to the sound patterns of native language words. Journal of Memory and Language, Berlin, v. 32, n. 3, p. 402-420, June 1993.

KABAK, B.; IDSARDI, W. Perceptual distortions in the adaption of English consonant clusters: Syllable structure or consonantal contact constraints?. Language and Speech, Berlin, v. 50, n. 1,p. 23-52, Mar. 2007.

KENNEDY, S.; TROFIMOVICH, P. Language awareness and second language pronunciation: a classroom study. Language Awareness, London, v. 19, n. 3, p. 171185, Dec. 2010.

KIVISTÖ-DE SOUZA, H. Phonological awareness and pronunciation in a second language. 2015. 505p. Dissertation (Ph.D. in Applied Linguistics) - University of Barcelona,Department of English Language and Literature, Barcelona, 2015.

KLUGE, D. Effects of preceding vowel in the perception of the English nasal consonants / $\mathrm{m}, \mathrm{n} /$ in word-final position by Brazilian EFL learners. Diadorim, Rio de Janeiro, v. 12, n. 1, p. 167-173, Jan. 2012. 
KOVÁCS, G.; RACSMÁNY, M. Handling L2 input in phonological STM: The effect of non-L1 phonetic segments and non-L1 phonotactics on nonword repetition. Language Learning, Michigan, n. 58, n. 3, p. 597-624, Sept. 2008.

LUCE, P.; PISONI, D. Recognizing spoken words: The neighborhood activation model. Ear \& Hearing, Alphen aan den Rijn, v. 19, n. 2, p. 1-36, Apr. 1998.

MACKAY, I.; FLEGE, J.; IMAI, S. Evaluating the effects of chronological age and sentence duration on degree of perceived foreign accent. Applied Psycholinguistics, Cambridge, v.27, n. 2, p. 157-183, Mar. 2006.

MAGEN, S. H. The perception of foreign-accented speech. Journal of Phonetics, Amsterdam, v. 26, n. 4, p. 381-400, Oct. 1998.

MATTYS, S.; JUSCZYK, P. Phonotactic cues for segmentation of fluent speech by infants. Cognition, Berlin, v. 78, n. 2, p. 91-121, Feb. 2001.

MCQUEEN, J. Segmentation of continuous speech using phonotactics. Journal of Memory and Language, Berlin, v. 39, n. 1, p. 21-46, Jan. 1998.

MEARA, P. M. X_Lex: The Swansea vocabulary levels test (Version 2.05.). Computer software. Swansea: Lognostics, 2005.

MIKHAYLOVA, A. L2 nonword recognition and phonotactic constraints. University of Pennsylvania Working Papers in Linguistics, Philadelphia, Penn Graduate Linguistics Society, v. 15, n. 1 [Proceedings of the 32nd Annual Penn Linguistics Colloquium], p. 145-152, 2009.

MILTON, J. The development of vocabulary breadth across the CEFR levels: A common basis for the elaboration of language syllabuses, curriculum guidelines, examinations, and textbooks across Europe. In: BARTNING, I.; MARTIN, M.; VEDDER, I. (Org.). Eurosla Monographs Series 1: Communicative Proficiency and Linguistic Development. EUROSLA, 2010. p. 211-232. Retrieved from <http:/ / eurosla.org/monographs/EM01/EM01 tot.pdf > . Accessed on: Oct. 10 2016.

MORA, J.C; ROCHDI, Y., KIVISTÖ-DE SOUZA, H. Mimicking accented speech as L2 phonological awareness. Language Awareness, London, v.23, n. 1-2, p.57-75, February,2014.

PALLIER, C.; COLOMÉ, A; SEBASTIÁN-GALLÉS, N. The influence of nativelanguage phonology on lexical access: Exemplar-based versus abstract lexical entries. Psychological Science, Los Angeles, v. 12, n. 6, p. 445-449, Nov. 2001.

PEXMAN, P; LUPKER, S; JARED, D. Homophone effects in lexical decision. Journal of Experimental Psychology: Learning, Memory and Cognition, Washington, v. 27, n. 1, p. 139-156, Jan. 2001.

PISKE, T., MACKAY, I. R. A.;FLEGE, J. Factors affecting degree of foreign accent in an L2: A review. Journal of Phonetics, Amsterdam, v. 29, n. 2, p. 191-215, Apr. 2001. 
PRAAMSTRA, P; MEYER, A; LEVELT, W. Neurophysiological manifestations of phonological processing: Latency variation of a negative ERP component timelocked to phonological mismatch. Journal of Cognitive Neuroscience, Massachusetts, v. 6, n. 3, p. 204-219, June 1994.

RAMÍREZ VERDUGO, D. A study of intonation awareness and learning in nonnative speakers of English. Language Awareness, London, v. 15, n. 3, p. 141-159, Jan. 2006.

RATO, A. Cross-language perception andproduction of English vowels by Portuguese learners: the effects of perceptual training. 2013. 375p. Dissertation (Ph.D. inLanguage Sciences) - University of Minho, Instituto de Letras e Ciências Humanas, Minho, 2013.

RAUBER, A. Production of English initial /s/-clusters by speakers of Brazilian Portuguese and Argentine Spanish. In: BAPTISTA, B. O.; WATKINS, M. A. (Org.). English with a Latin beat: Studies in Portuguese/ Spanish-English interphonology. Amsterdam: John Benjamins, 2006. p. 155-169.

REBELLO, J.; BAPTISTA, B. O. The influence of voicing on the production of initial /s/-clusters by Brazilian learners. In: BAPTISTA, B. O.; WATKINS, M. A. (Org.). English with a Latin beat. Studies in Portuguese/Spanish-English interphonology. Amsterdam: John Benjamins, 2006. p. 139-154.

SAITO, K. The acquisitional value of recasts in instructed second language speech learning: Teaching the perception and production of English / $\mathrm{I} /$ to adult Japanese learners. Language Learning, Michigan, v. 63, n. 3, p. 499-529, Sept. 2013.

SAITO, K.; WU, X. Communicative focus on form and second language suprasegmental learning: Teaching Cantonese learners to perceive Mandarin tones. Studies in Second Language Acquisition, Cambridge, v. 36, n. 4, p. 647-680, Sept. 2014. SCHMID, M. HOPP, H. Comparing foreign accent in L1 attrition and L2 acquisition: Range and rater effects. Language Testing, Berlin, v. 31, n. 3, p. 367-388, July 2014.

SCHMIDT, R. Consciousness and foreign language learning: a tutorial on the role of attention and awareness in learning. In: SCHMIDT, R. (Org.). Attention and awareness. Honolulu: University of Hawai' $i$, National Foreign Language Resource Center, 1995. p. 1-63.

SILVEIRA, R. Perception and production of English initial /s/ clusters by Brazilian learners. Revista Brasileira de Linguistica Aplicada, Belo Horizonte, v. 2 n. 1, p. 95-119, 2002. 
STONE, G.; VAN ORDEN, G. Strategic control of processing in word recognition. Journal of Experimental Psychology: Human Perception and Performance, Washington, v. 19, n. 4, p. 744-774, Aug.,1993.

TRAPMAN, M.; KAGER, R. The acquisition of subset and superset phonotactic knowledge in a second language. Language Acquisition, London, v. 16, n. 3, p. 178221, June 2009.

TROFIMOVICH, P.; BAKER, W. Learning second language suprasegmentals: Effect of L2 experience on prosody and fluency characteristics of L2 speech. Studies in Second Language Acquisition. Cambridge, v. 28, n. 1, p. 1-30, Jan. 2006.

VANPATTEN, B. Input processing and grammar instruction in second language acquisition. Norwood: Ablex Publishing, 1996.

VITEVITCH, M.; LUCE, P. When words compete: Levels of processing in perception of spoken words. Psychological Science, Los Angeles, v. 9, n. 4, p. 325-329, Sept. 1998.

VITEVITCH, M.; LUCE, P. Probabilistic phonotactics and neighborhood activation in spoken word recognition. Journal of Memory and Language, Berlin, v. 40, n. 1, p. 374-408, Jan. 1999.

VITEVITCH, M.; LUCE, P. A web-based interface to calculate phonotactic probability for words and nonwords in English. Behavior Research Methods, Instruments, and Computers, Berlin, v. 36, n. 3, p. 481-487, Aug. 2004.

VITEVITCH, M.; LUCE, P.; CHARLES-LUCE, J.; KEMMERER, D. Phonotactics and syllable stress: Implications for the processing of spoken nonsense words. Language and Speech, Berlin, v. 40, n. 1, p. 47-62, Jan. 1997.

WEBER, A.; CUTLER, A. First-language phonotactics in second-language listening. The Journal of the Acoustical Society of America, New York, v. 119, n. 1, p. 597-607, Jan. 2006.

WREMBEL, M. PHONOLOGICAL METACOMPETENCE IN THE ACQUISITION OF SECOND LANGUAGE PHONETICS. 2005. 450p. Dissertation (Ph.D. in English Language) -Adam Mickiewicz University, Faculty of English, Poznan, 2005.

WRIGHT, B.; GARRETT, M. Lexical decision in sentences: Effects of syntactic structure. Memory \& Cognition, Berlin, v. 12, n. 1, p. 31-45, Jan. 1984.

YAVAŞ, M. Applied English phonology (2nd ed.). Oxford: Wiley-Blackwell, 2011.

Data de submissão: 03/07/2016. Data de aprovação: 29/08/2016. 